\title{
Financial inclusion, bank competition and economic growth in Africa
}

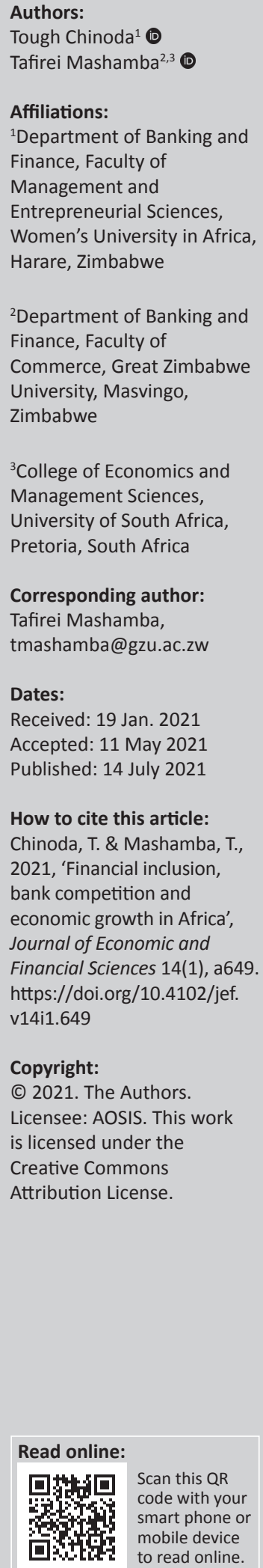

Orientation: The relevance of bank competition and economic growth for boosting financial inclusion is attracting unprecedented attention from academics and policymakers, mainly because of several persisting issues which, if addressed, can enhance the functionality of governments, businesses, individuals and the economy.

Research purpose: The study aims to examine the interplay between financial inclusion, bank competition and economic growth in Africa.

Motivation for the study: Previous literature focuses mainly on the nexus between financial inclusion and bank competition, financial inclusion and economic growth and bank competition and economic growth producing diverse results, with a dearth of literature on the trivariate link between the three variables.

Research approach/design and method: This study employed the pooled mean group estimation-based panel autoregression distribution lag approach from 2004 to 2018. A panel data analysis for 20 African countries was used.

Main findings: The study found a significant positive relationship between financial inclusion and economic growth in the long run. However, in the short run, economic growth significantly reduces financial inclusion. We also found that in the long-run bank competition reduces financial inclusion in line with the information hypothesis. However, in the short run the effect is significantly positive, consistent with the market power hypothesis.

Practical/managerial implications: Policymakers and development agencies should implement measures that reckon incentives that can accelerate bank competition to bring on-board the unbanked. They should also take note of financial inclusion measurement in addressing financial inclusion challenges. Moreover, they should minimise barriers to financial inclusion to enhance bank competition and stability.

Contribution/value-add: The study managed to discover how bank competition and economic growth influences financial inclusion.

Keywords: bank competition; financial inclusion; economic growth; panel auto regression distribution lag; pooled mean group.

\section{Introduction}

Since 2010, the World Bank has fronted the initiative for increased financial inclusion to help eradicate poverty in emerging economies (Global Partnership for Financial Inclusion [GPFI] 2010). At present, the relevance of bank competition and financial inclusion for economic growth and poverty reduction is attracting unprecedented attention from academics and policymakers. This is because of several persisting issues which, if addressed, can enhance the functionality of governments, businesses, individuals and the economy. Amongst the emerging economies, financial inclusion is lowest in Africa (Mehrotra \& Yetman 2015). The World Bank statistics show that only $54 \%$ of the adult population in Africa have bank accounts compared with $94 \%$ in the Organisation for Economic Co-operation and Development (OECD) high-income economies (Demirgüç-Kunt, Klapper \& Singer 2017). The discrepancy is a result of distance, cost of opening and maintaining bank accounts and documentation requirements, which are high in emerging economies compared with developed economies (Demirgüç-Kunt et al. 2018). Much of the literature on financial inclusion in Africa focuses on how financial inclusion contributes to economic growth. The role of bank competition in these relationships is often only reflected in the periphery if it is considered at all.

This article is motivated by the dearth of empirical studies and the existence of an ongoing practical debate on the nexus between financial inclusion and economic growth, bank competition 
and economic growth and also between financial inclusion and bank competition in Africa. Various methodologies that have their merits and demerits have been used to investigate the interplay between financial inclusion and economic growth, bank competition and economic growth and also between financial inclusion and bank competition in Africa. These methods include ordinary least squares (Evans 2015; Okoye, Erin \& Modebe 2017; Otiwu et al. 2018), Granger causality test with autoregressive distribution lag (ARDL) (Bigirimana \& Hongyi 2018; Lenka \& Sharma 2017; Sethi \& Sethy 2018), generalised method of moments (Andrianaivo \& Kpodar 2012), panel vector autoregression (Kim, Yu \& Hassan 2018; Sharma 2016). Concomitantly, studies by Mengistu and Saiz (2018), Owen and Pereira (2018) and Marin and Schwabe (2019) concluded a positive relationship between bank competition and financial inclusion in line with the market-structure hypothesis, whilst Love et al. (2014) and Azer et al. (2019) maintained an inverse relationship between the two variables in support of the information-based hypothesis.

Bank competition is linked with financial access, capital allocation and economic growth. Competition motivates companies to innovate, reduce prices for products or services and increase quality, which sequentially increases consumer choice and enhances growth (Amidu \& Wilson 2014; Rakshit \& Bardhan 2019). However, borrowers are unwilling to borrow as a result of hold-up problems, which successively lowers loan financing demand, in a less competitive environment. Moreover, service quality is usually lower and prices are higher in a less competitive environment, which eventually leads to lesser demand and affects growth (Claessens 2009). The results of the study by Banya and Biekpe (2017) supported the hypothesis that banking sector competition positively impacts economic growth. On the other hand, Ijaz et al. (2020) found that lower banking competition supports economic growth for European countries.

Meanwhile, previous studies on the interplay between financial inclusion and economic growth in Africa produced diverse results, thus leaving policymakers and the academia in dilemma attributable to the unsettled nature of link between these two variables. Findings from some studies support the supply-leading hypothesis, which claims that financial inclusion leads to economic growth (Iqbal \& Sami 2017; Lenka \& Sharma 2017; Mwaitete \& George 2018; Onaolapo 2015; Sharma 2016; Van et al. 2019). Others concluded a significant positive relationship between financial inclusion and economic growth in line with the demand following hypothesis (Babajide, Adegboye \& Omankhanlen 2015; Evans 2015). In the same vein, Evans and Lawanson (2017), Sethi and Acharya (2018) and Kim, Yu and Hassan (2018), amongst others, concluded a bidirectional relationship between financial inclusion and economic growth. On the extreme, Barajas, Chami and Yousefi (2013) maintained that the relationship is negative. The implication that appears from these studies is that the nexus between financial inclusion and economic growth is empirically and theoretically ambiguous.
Unlike these studies, we employed the panel ARDL approach proposed by Pesaran, Shin and Smith (1999) to investigate the nexus between financial inclusion, bank stability and bank competition. Our study brings in two contributions. Firstly, by using a panel ARDL model approach, the speed of adjustment and the long-run level relationships in the financial inclusion dynamic equation becomes of particular interest to the African countries as it relates to the viability of the economic growth and stability pact. Secondly, as shortrun coefficients can vary across groups using the pooled mean group (PMG) estimation method, the results become vital especially when crafting medium-term country-specific budgetary objectives so as to guide policymakers on actions to be taken. Thirdly, there is no study we are aware of that investigates the trivariate linkage amongst financial inclusion, bank competition and economic growth.

This study aimed to investigate the relationship amongst financial inclusion, bank competition and bank stability in Africa covering a period of 2004-2018. These countries include Algeria, Angola, Botswana, Cameroon, Egypt, Ethiopia, Gambia, Ghana, Kenya, Madagascar, Malawi, Morocco, Nigeria, Rwanda, South Africa, Swaziland, Tanzania, Tunisia, Uganda and Zambia.

The rest of this article is structured as follows: the next section entitled 'Literature review' examines related literature; the 'Methodology' section lays out the research methodology; the 'Empirical result' section presents the results whilst the 'Conclusions and policy implications' section presents the conclusion and policy implications of the study.

\section{Literature review}

\section{Financial inclusion and economic growth}

There is no consensus over the definition of financial inclusion as differences stem from the geographical location of the area and the milieu in which the term is used. We defined financial inclusion as the process of ensuring easy access to or use of affordable financial services and products that suit businesses and individuals necessities, conveyed in a viable and responsible manner. The literature on finance-growth nexus can be categorised into four varied hypotheses, namely, 'supply-leading', 'demand-following', 'feedback hypothesis' and the 'neutral hypothesis'. The 'finance-led growth', also known as the 'supply-leading' hypothesis suggests a positive impact of financial inclusion on economic growth. There are four diverse channels through which financial inclusion boosts economic growth: the role of financial intermediation in resources allocation from the surplus to the deficit units, henceforth improving resource distribution (Mishkin \& Serletis 2011; Sharma 2016); the provision of a dependable and low-cost payment services to low-income groups (Babajide et al. 2015); risk management services (Muhoza 2019); and the provision of the investment and capital information in the economic system (Levine 2005). The 'supply-leading' hypothesis empirically shows that financial inclusion augments economic growth. In literature, several studies buttressed this hypothesis (e.g. Andrianaivo \& 
Kpodar 2012; Bayar \& Gavriletea 2018; Gretta 2017; Oruo 2013). This hypothesis was upheld in studies that were conducted in developing countries, either as a panel (Gretta 2017; Iqbal \& Sami 2017) or individual countries, such as Evans (2017) and Otiwu et al. (2018) in Nigeria and Mwaitete and George (2018) in Tanzania. Likewise, Dahiya and Kumar (2020) examined the interplay between financial inclusion and economic growth in India from 2004 to 2014 and concluded that financial inclusion drives economic growth.

The growth-led finance also known as the 'demandfollowing' hypothesis advocates a positive impact of economic growth on financial inclusion (Evans 2015). This theory contends that financial services demand increases as the economy grows following the demand from economic agents such as investors (Sahay et al. 2015). Economic growth then attracts private businesses and individuals to invest in a country, thus enhancing their demand for financial services (Babajide et al. 2015). Evans (2015) and Evans and Alenoghena (2017) concluded a positive effect of economic growth on financial inclusion in Africa after applying the Granger causality test and Bayesian VAR, respectively. On the other hand, a bidirectional relationship can exist between financial inclusion and economic growth, denoting a dependence between financial inclusion and economic growth. At the first stage, as a real impulse, the economy requires investment funds from financial institutions. Individuals save as the economy reaches self-sustenance and investors step up their borrowing, to invest in real projects as more investment opportunities arise (Gour'ene \& Mendy 2017; Sethi \& Acharya 2018). Other scholars view the relationship as neutral (unimportant or absent), implying that the two variables do not influence each other (e.g. Gour'ene \& Mendy 2017; Khalaf \& Ali 2015). From this discussion, it can be seen that evidence on the nexus between financial inclusion and economic growth is mixed, warranting further investigation. This study seeks to add literature using the ARDL.

\section{Bank competition and financial inclusion}

The interplay between financial inclusion and bank competition has produced conflicting results, resulting in the emergence of two contrary hypotheses, namely, the information-based hypothesis and market power hypothesis. The market power hypothesis suggests that competition causes banks with low-profit margins to become more clientdriven as they raise their efficiency and expand their outreach (Boot \& Thakor 2000), thereby enhancing financial services accessibility and availability. Moreover, competition causes banks to take risks to increase returns by providing loans to sub-prime borrowers (Berger, Klapper \& Turk-Ariss 2009). Studies by Mengistu and Saiz (2018), Owen and Pereira (2018) and Marin and Schwabe (2019) concluded a positive relationship between bank competition and financial inclusion in line with the market-structure hypothesis. The information hypothesis postulates that bank competition negatively affects financial inclusion. Banks need to screen loan applicants because of information asymmetries. However, competition reduces the banks' incentives to screen their loan applicants' ex ante as a result of information externalities (Hauswald \& Marques 2006). Thus, competition lowers the probability of a bank to grant a loan (Marquez 2002), which unfavourably affects financial inclusion. CarboValverde, Rodriguez-Fernandez and Udell (2009) concluded that bank competition reduces firms' financial constraints in Spain. On the other hand, Love and Martinez-Peria (2014) and Azer et al. (2019) concluded an inverse relationship between bank competition and financial inclusion in Europe, supporting the information-based hypothesis.

\section{Economic growth and bank competition}

Theoretical opinions suggest that bank competition can have numerous opposing effects on the macroeconomy. The traditional view asserts that economies grow faster as bank competition increases; hence, market power is presumed to be bad and linked with inefficiencies and rent extraction (Guzman 2000). In contrast, Chortareas, Girardone and Ventouri (2011) maintained that market power is beneficial as it allows banks to surmount informational asymmetries and create productive relationships with young entrepreneurs. Bank competition is vital as it has an impact on the efficiency of financial services provision, the degree of financial innovation and the quality of financial products in the market (Claessens 2009). Claessens and Laeven (2005) further contended that the level of banking competition can have an impact on the access of firms and households to banking products, which sequentially influences overall economic growth. Empirical evidence on the interplay between economic growth and bank competition is also mixed, warranting further investigation. Idun and Aboagye (2014) investigated the interplay between economic growth, bank competition and financial innovation in Ghana using the bound test ARDL and Granger causality test. They found a positive relationship between economic growth and bank competition in the long run, but the relationship was negative in the short run. This suggests that bank competition does not result in instant economic gain as only a gradually growing competitive banking system makes the difference. This analysis is in line with Asante, Agyapong and Adam (2011) who found that in the long run competition Granger causality test causes economic growth in Ghana. Banya and Biekpe (2017) investigated the nexus between bank competition and economic growth for a panel of 10 African countries from 2005 to 2012. They concluded that bank competition improves economic growth in Africa. However, Idun and Aboagye (2014) found an inverse relationship between economic growth and bank competition in Ghana.

\section{Methodology Data and variables description}

Data for 23 African countries, namely, the financial inclusion index (FII), bank competition (BOONE) and economic growth (GDPPCG) were sourced from the World Bank Development Indicators over the period 2004-2018. Data availability mainly on financial inclusion variables which are available from 2004 guided the choice of the study. Variables 
definitions are shown in Table 1. We applied the dynamic panel data model for the balanced panel because it permits us to control for model endogeneity problems. There is no universal measure of bank competition in the literature and following Banya and Biekpe (2017) we used the Boone indicator as an indicator for bank competition. The Boone indicator is a more topical New Empirical Industrial Organisation methodology for measuring competition. Following Gourené and Mendy (2017), this study used GDP per capita growth as an indicator of economic growth. Gross domestic product per capita growth measures closest to the definition of economic growth and also allows for crosscountry comparisons and capturing of income distribution effects. There exists no universal definition of financial inclusion, and we adopted the World Bank (2017) definition as the process of ascertaining access to or use of affordable financial services and products that suit the necessities of businesses and individuals, conducted in a viable and answerable manner. Hence, for robustness of results in this study, we employed several dimensions of financial inclusion in computing a comprehensive index of financial inclusion. The FII is best at measuring financial inclusion as it embraces all the financial inclusion dimensions, and it also has strong theoretical basis making it a better choice for the study. Following Sarma's (2008) arguments, this study used usage, availability and accessibility as dimensions of the FII as they broadly proxy financial inclusion, which is multidimensional. This is contrary to other studies that used one variable such as banking penetration, availability of banking services or usage of banking services in terms of deposits to represent financial inclusion. Following the footsteps of Sarma (2008), we used equation (1) to compute the indicator for each dimension:

$\aleph_{i, d}=\frac{\chi_{i}-m_{i}}{M_{i}-m_{i}}$

[Eqn 1]

where $\boldsymbol{N}_{i}$ is the value of indicator $i, m_{i}$ is the minimum value of indicator $i$ and $M_{i}$ is the maximum value of dimension $i . \boldsymbol{\aleph}_{i, d}$ is the standardised value of indicator $i$ with $d$ as the dimension. Employing the principal component analysis (PCA) each indicator was aggregated to a dimension index in line with Camara and Tuesta (2014). We selected $\lambda_{k}(k=1 \ldots p)$ as the $k^{\text {th }}$ eigenvalue, subscript $k$ as the principal components number that ties with the standardised indicators $p$. The $i^{\text {th }}$ principal component was designated by $P_{l}(k=1 \ldots p)$ and we also hypothesised that $\lambda_{1}>\lambda_{2}>\ldots \lambda_{p}$. We derived each dimension index corresponding to the weighted averages: standardised. In line with Camara and Tuesta (2014), we considered all the total variations in the indices of dimensions to evade information that could accurately estimate the overall country's index of financial inclusion. We ran another PCA as shown in Equation 2 to compute the dimension weights for inclusive financial inclusion. $\omega$ signifies the weights from the PCA and $\aleph_{i}$ are the dimensions:

$F I I_{I}=\omega_{1} \aleph_{1 k}+\omega_{2} \aleph_{2 k}+\omega_{3} \aleph_{3 k}$
The panel ARDL approach (PMG) estimation methodology is applicable when some variables are integrated of order 1 or 0 . We conducted some unit root tests (Levin-Lu and Chu [LLC] test) to determine the order of the variables integration and the nature of variables stationarity (Choi 2001). The study used the Akaike information criterion (AIC) to determine the optimal lag length. In addition, we employed the Hausman test (Hausman 1978) to determine the suitable model to use between the mean group (MG), PMG, and the dynamic fixed effects (DFEs).

\section{Panel autoregressive distribution lags}

We used the panel autoregressive distribution lags (ARDL) PMG approach to investigate the long-run relationship for the panel of countries. The study employed the Hausman test to determine the most apt estimation technique from the MG, PMG and DFE. Financial inclusion, bank competition and economic growth are persistently justifying the suitability of the dynamic model. We used the ARDL model and the error correction model (ECM) to jointly estimate the short- and longrun effects of the panel data. Comparing time series data with panel data, panel data assumes heterogeneity whereas time series assumes data homogeneity (Baltagi 1999). Model misspecifications usually occur when heterogeneity is disregarded (Baltagi 2008). We employed the panel ARDL procedures of MG, PMG and DFE to determine the relationship between the variables as suggested by Pesaran et al. (1999). These techniques are suitable when estimating non-stationary dynamic panels for heterogeneous parameters across groups. Panel data also give the researcher numerous data points thus improving the efficiency of the econometric as the degrees of freedom are increased reducing multicollinearity amongst the study variables (Baltagi 2008; Hsiao 2014).

The MG estimator runs distinct cross section equations and average the model parameters to produce consistent estimators (Pesaran et al. 1999). On the other hand, the PMG estimator includes the characteristics of the MG and groups the estimators (Pesaran et al. 1999). The PMG estimation also assumes consistency and the independence of the regression residuals across countries (Loayza \& Rancière 2006). The PMG also allows for the speed of adjustment to the long-run equilibrium values across countries (Loayza \& Rancière 2006; Pesaran et al. 1999). In our study, bank competition and economic growth are determinants of financial inclusion. Our study hypothesises financial inclusion as a function of bank competition and economic growth. We used the following ARDL equations to examine the relationship between financial inclusion, bank competition and economic growth in Africa:

$$
\begin{aligned}
F I I_{i, t}= & \beta_{0}+\beta_{1 i} F I I_{i, t-1}+\beta_{2 i} \text { BOONE }_{i, t-1}+ \\
& \beta_{3 i} G D P P C G_{i, t-1}+\sum_{i=0}^{n} \Psi_{1, t} \Delta F I I_{i, t-1}+ \\
& \sum_{i=0}^{n} \Psi_{2, t} \Delta B O O N E_{i, t-1}+ \\
& \sum_{i=0}^{n} \Psi_{3, t} \Delta G D P P C G_{i, t-1}+\varepsilon_{i, t}
\end{aligned}
$$


where BOONE is the Boone indicator that was used as proxies for bank competition in this study, FII is the financial inclusion index and GDPPCG is the gross domestic product per capita growth, which is a proxy for economic growth:

$\beta \mathrm{s}$ are the independent variables long-run coefficients.

$\Psi$ s are the coefficients in the short run.

$\varepsilon_{i t}$ is the error term where $t$ and $i$ represent the time period and the country, respectively.

\section{Error correction model}

Having determined the long-run relationship between financial inclusion, bank competition and economic growth, the study then determines the effects in the short-run using the panel-vector ECM (Apergis \& Payne 2010). The ECM captures the short- and long-run effects giving it an edge over other methods (Engle \& Granger 1987; Hoffman \& Rasche 1996). This study proposed the following generic ECM equation:

$$
\begin{aligned}
\Delta F I I_{i, t}= & \alpha_{0 t}+\alpha_{1} \sum_{i=1}^{p} \Delta F I I_{i . t-1}+\alpha_{2} \sum_{i=1}^{p} \Delta B O O N E_{i, t-1} \\
& +\alpha_{3} \sum_{i=1}^{p} \Delta G D P P C G_{i, t-1}+\lambda E C T_{I, T}+\mu_{i, t-1}
\end{aligned}
$$

where ECT is the error correction term, $p$ is the AIC selected lag length, BOONE is the Boone indicator, a proxy for bank competition, FII is the financial inclusion index and GDPPCG is the gross domestic product per capita growth, which is a proxy for economic growth.

$\alpha_{0}$ is the constant, $\lambda$ is the long-run equilibrium adjustment speed, and $\mu$ is the error term.

The system's adjustment speed to the equilibrium in the long run after a short-run shock is explained by the ECT coefficient in the ECM equations. The coefficient of the ECT is expected to be negative and statistically significant, showing how the variables converge to the equilibrium level (Bildirici \& Kayıkçı 2013).

\section{Empirical results Descriptive statistics}

The descriptive statistics for the variables used in the study

\begin{tabular}{|c|c|c|c|}
\hline Variables & Indicator & Definition & Reference \\
\hline $\begin{array}{l}\text { Bank } \\
\text { competition }\end{array}$ & BOONE & $\begin{array}{l}\text { Changes in bank } \\
\text { concentration levels }\end{array}$ & Banya and Biekpe (2017) \\
\hline $\begin{array}{l}\text { Economic } \\
\text { growth }\end{array}$ & GDPPCG & $\begin{array}{l}\text { The percentage change } \\
\text { in per capita GDP, used } \\
\text { as our indicator of } \\
\text { economic growth. }\end{array}$ & $\begin{array}{l}\text { Gourené and Mendy } \\
\text { (2017) }\end{array}$ \\
\hline \multirow[t]{4}{*}{$\begin{array}{l}\text { Financial } \\
\text { inclusion index }\end{array}$} & Usage & $\begin{array}{l}\text { Credit to the private } \\
\text { sector }\end{array}$ & Sarma $(2008,2012)$ \\
\hline & $\begin{array}{l}\text { Banking } \\
\text { penetration }\end{array}$ & $\begin{array}{l}\text { Depositors with } \\
\text { commercial banks }\end{array}$ & $\begin{array}{l}\text { Adeola and Evans (2017); } \\
\text { Evans (2015); Sarma } \\
(2008,2012)\end{array}$ \\
\hline & Access & $\begin{array}{l}\text { ATMs per } 100000 \\
\text { adults }\end{array}$ & $\begin{array}{l}\text { Adeola and Evans (2017); } \\
\text { Rasheed et al. (2016) }\end{array}$ \\
\hline & & $\begin{array}{l}\text { Commercial bank } \\
\text { branches per } 100000 \\
\text { adults }\end{array}$ & $\begin{array}{l}\text { Sarma (2008); Kumar } \\
\text { (2013); Rasheed et al. } \\
\text { (2016) }\end{array}$ \\
\hline
\end{tabular}
are presented in Table 2 .

GDPPCG, economic growth; BOONE, bank competition.
On average, financial inclusion level in Africa is very low at $27 \%$. The maximum and minimum values of financial inclusion in Africa between 2004 and 2018 are 0.72 and 0.13, respectively, implying that African countries are characterised by serious financial inclusion disparities in line with Mehrotra and Yetman (2015). The mean bank competition proxied by the Boone indicator was -0.081 , indicating a less intense competitive banking landscape in Africa. The mean economic growth in Africa is 2.63\%, indicating that the economic output for African economies under investigation was 2.63\% between 2004 and 2018.

\section{Stationarity tests results}

The results in Table 3 show that economic growth (GDPPCG) and bank competition (BOONE) are stationary at level I (0) whilst FII is stationary after first difference 1(1). Using the Akaike information criteria (AIC), Hannan and Quinn criteria (HQC) and Schwarz information criteria (SIC), the lag length of three was found to be appropriate in each equation (see Figure 2-A1 in Appendix 1).

\section{Cointegration test}

We checked for the long-run relationship between the variables using the Johansen and Juselius (1990) procedure. The results are presented in Table 4 . The trace test and the maximum eigenvalue test indicate two cointegration relationships which show that there exists a long-run relationship between the variables under study.

\section{Panel autoregressive distribution lag results}

This study discusses the results of the error correction and cointegration amongst financial inclusion, bank competition and economic growth in Africa. The study used the PMG, which assumes an identical long-run relationship amongst financial inclusion, bank competition and economic growth across countries, whilst allowing a country-specific short-run relationship. The study used the Hausman test to verify the coefficients' long-run homogeneity as Table 5 reports the PMG estimation results of the financial inclusion dimensions'

TABLE 2: Descriptive statistics.

\begin{tabular}{lccccc}
\hline Variable & Obs. & Mean & s.d. & Min & Max \\
\hline FII & 345 & 0.273 & 0.131 & 0.132 & 0.72 \\
GDPPCG & 345 & 2.630 & 3.562 & -9.216 & 30.36 \\
BOONE & 345 & -0.081 & 0.284 & -3.200 & 1.13 \\
\hline
\end{tabular}

FII, financial inclusion index; GDPPCG, gross domestic product per capita growth; BOONE, bank competition; s.d., standard deviation; Obs., observations; Min, minimum; Max, maximum.

TABLE 3: Levin Lu and Chu unit root test @ I (0) and 1(1) level.

\begin{tabular}{lccccc}
\hline Variable & \multicolumn{2}{c}{ LLC@ 1(0) } & & \multicolumn{2}{c}{ LLC @1(1) } \\
\cline { 2 - 3 } \cline { 5 - 6 } \cline { 5 - 6 } & Stats & $\boldsymbol{p}$ & & Stats & $\boldsymbol{p}$ \\
\hline GDPPCG & -16.7 & 0.00 & & -20.5 & 0.00 \\
FII & -5.02 & 0.60 & & -5.35 & 0.00 \\
BOONE & -6.05 & 0.02 & & -15.9 & 0.00 \\
\hline
\end{tabular}

LLC, Levin Lu and Chu; FII, financial inclusion index; GDPPCG, gross domestic product per capita growth; BOONE, bank competition. 
TABLE 4: Results of the cointegration test.

\begin{tabular}{lcccc}
\hline No of CEs & Statistic & Eigenvalue & Critical value & Prob. ${ }^{* *}$ \\
\hline None* $^{*}$ & 108.44 & 0.1206 & 65.849 & 0.000 \\
At most 1* & 62.361 & 0.1040 & 42.586 & 0.000 \\
At most 2* & 30.893 & 0.0450 & 29.733 & 0.022 \\
At most 3 & 9.0032 & 0.0216 & 15.324 & 0.370 \\
At most 4 & 0.4437 & 0.0036 & 3.815 & 0.470 \\
\hline
\end{tabular}

CEs, cointegration estimates; Prob., probability of the outcome.

*, denotes rejection of the hypothesis at $5 \%$ level; **, denotes MacKinnon-Haug-Michelis (1999) $p$-values.

long-run and short-run coefficients and the error correction term coefficient.

The results in Table 5 show that there is a significant positive relationship between financial inclusion and economic growth in the long run. An increase in the economic growth boosts financial inclusion in the long run. This is in line with an intuitive expectation of a positive relationship between financial inclusion and economic growth. Theory has mixed results on the effects of economic growth on financial inclusion as the relationship can either be positive or negative (Gour'ene \& Mendy 2017). Scholars in support of the 'demand-following' hypothesis or the growth-led finance uphold that a positive relationship exists between economic growth and financial inclusion (Evans 2015). They argue that economic growth increases the demand for financial services as the economy grows following the demand from economic agents such as investors (Sahay et al. 2015). Economic growth attracts private individuals and businesses to invest in a country, thereby enhancing their demand for financial services (Babajide et al. 2015). Other scholars opine that the relationship is neutral (absent or unimportant), implying that financial inclusion and economic growth do not influence each other (e.g. Gour'ene \& Mendy 2017; Khalaf \& Ali 2015).

Table 5 also reveals a significant negative effect of bank competition (Boone) on financial inclusion in the long run. The bank competition coefficient of -0.67 indicates that a $1 \%$ increase in bank competition leads to a $67 \%$ reduction in financial inclusion in Africa in the long term. Our results are in line with the information hypothesis. The information hypothesis suggests an inverse relationship between bank competition and financial inclusion. Information asymmetries cause banks to screen loan applicants. However, competition reduces the banks' incentives to screen their loan applicants' ex ante because of information externalities (Hauswald \& Marques 2006). Thus, competition lowers the probability of a bank to grant a loan (Marquez 2002), which unfavourably affects financial inclusion. Our results however contradict scholars in support of the market power hypothesis which suggests a positive relationship between the two variables.

Lack of competition and monopoly power, which characterise most banks in developing countries, enable them to charge higher spreads (Allen \& Gale 2004). As a result of the higher spreads, the poor are discouraged from participation in the formal financial sector by the poor (financial exclusion). Alternatively, banks may not
TABLE 5: Pooled mean group estimation results (Boone) - (2004-2018).

\begin{tabular}{lcccc}
\hline D.fii & Coefficient & Std. error & $\mathbf{z}$ & $p>|\mathbf{z}|$ \\
\hline LR_ec & & & & \\
Gdppcg & 0.0228 & 0.0058 & 3.91 & $0.000^{*}$ \\
Boone & -0.6728 & 0.3306 & -2.04 & $0.042^{* *}$ \\
SR & & & & \\
ec & -0.4671 & 0.0680 & -6.87 & $0.000^{*}$ \\
Gdppcg & -0.0121 & 0.0017 & -7.22 & $0.000^{*}$ \\
Boone & 0.4275 & 0.2195 & 1.95 & $0.051^{* * *}$ \\
_cons & 0.1290 & 0.0294 & 4.39 & $0.000^{*}$ \\
\hline
\end{tabular}

Note: For all $p$-values: *, $1 \%$ significance level; $* *, 5 \%$ significance level; $* * *, 10 \%$ significance level.

LR, long run; SR, short run; Std. error, standard error; D.fii, first difference of financial inclusion index.

increase product offerings that suit the poor (who lacks collateral) as they depend on profits from the highly charged spreads (Zhang \& Naceur 2019). To our knowledge, the role of bank competition in enhancing financial inclusion is empirically under-researched. Hence, the cost of credit can be a barrier to participation in formal financial sector by the poor, resulting in the failure to unlock human capital that has a potential to reduce poverty. Higher spread means expensive credit, and it hurts the poor, whilst lower spread has a poverty-reducing effect as the cost of credit is cheaper and the poor and small businesses can access the credit, which they can use for consumption smoothing, capital accumulation and risk management.

A look at the short-run financial inclusion dynamics in Table 5 reveals that economic growth reduces financial inclusion in Africa. The coefficient of -0.0121 shows that a $1 \%$ change in economic growth reduces financial inclusion by $1.21 \%$. The effect of economic growth is significant at $1 \%$ level. On the other hand, bank competition increases financial inclusion in Africa. A $1 \%$ change in bank competition will result in $46 \%$ increase in financial inclusion in Africa in the short run in line with the market power hypothesis. Bank competition in Africa causes banks with low-profit margins to become more clientdriven as they raise their efficiency and expand their outreach (Boot \& Thakor 2000), thereby enhancing financial services accessibility and availability. Moreover, competition causes banks to take risks to increase returns by providing loans to sub-prime borrowers (Berger et al. 2009). The error correction term is statistically significant at 5\% level and is also negative, which confirms cointegration relationship amongst the variables. The error correction term coefficient of -0.4651 shows a quick adjustment rate to the equilibrium of $47 \%$ per year whenever there is a shock to financial inclusion in the previous period. The relationship is statistically significant at the $1 \%$ significance level. Policymakers should enhance economic growth and bank competition, which latter feeds into financial inclusion. The results displayed for financial inclusion, bank competition and economic growth models passed the stability test. We also conducted the Hausman test to determine the suitable approach to use amongst the PMG, MG and DFE. As the probability in the Hausman test is above 5\%, we therefore used the PMG estimator and not the DFE estimator in our study. 


\section{Conclusion and policy implications}

This study employed the ARDL panel-based PMG estimator to explore the competition, financial inclusion and economic growth nexus. The results of the unit root test find that financial inclusion is 1 stationary, whereas bank competition and economic growth were 10 stationary, justifying the use of ARDL PMG estimator. The empirical finding reveals that the impact of economic growth on financial inclusion in Africa is positive and significant in the long run, although it was significantly negative in the short run. The findings therefore lend support to the growth-led finance hypothesis that financial inclusion leads to economic growth in the long run. In the short run our study's findings are in line with the neutral hypothesis, which contends a negative effect of economic growth on financial inclusion. A similar conclusion was reached by Evans and Alenoghena (2017) using the Bayesian VAR. This article, however, finds a significant negative effect of bank competition on financial inclusion in the long run. However, in the short run the effect is significantly positive consistent with the market power hypothesis. We thus recommend policymakers to implement strategies that reckon incentives that can accelerate bank competition, improve financial inclusion, and increase sustainable economic growth. Policymakers should also minify entrance barriers in the banking system and enhance bank competition.

\section{Acknowledgements Competing interests}

The authors have declared that no competing interest exists.

\section{Authors' contributions}

T.C. performed article conceptualisation, data analysis, writing the draft with input from T.M. and provided the statistical software and model validation. T.M. was responsible for research methodology with input from T.C., data curation, reviewing and editing of the manuscript.

\section{Ethical considerations}

This article followed all ethical standards for a research without direct contact with human or animal subjects.

\section{Funding information}

This research received no specific grant from any funding agency in the public, commercial or not-for-profit sectors.

\section{Data availability}

The data that support the findings of this study are openly available on the World bank website (www.databank. worldbank.org).

\section{Disclaimer}

The views and opinions expressed in this article are those of the authors and do not necessarily reflect the official policy or position of any affiliated agency of the authors.

\section{References}

Adeola, O. \& Evans, O., 2017, 'Financial inclusion, financial development, and economic diversification in Nigeria', The Journal of Developing Areas 51(3), 1-15.

Allen, F. \& Gale, D., 2004, 'Competition and financial stability', Journal of Money, Credit and Banking, 453-480.

Amidu, M. \& Wilson, J.O., 2014, 'Competition in African banking: do globalization and institutional quality matter?', Journal of Business Economics and Management 16(1), 192-211.

Andrianaivo, M. \& Kpodar, K., 2012, 'Mobile phones, financial inclusion, and growth', Review of Economics and Institutions 3(2), 30. https://doi.org/10.5202/rei.v3i2.75

Apergis, N. \& Payne, J.E., 2010, 'Renewable energy consumption and economic growth: evidence from a panel of OECD countries', Energy policy 38(1), 656-660.

Asante, S., Agyapong, D. \& Adam, A.M., 2011, 'Bank competition, stock market, and economic growth in Ghana', International Journal of Business Administration 2(4), 33. https://doi.org/10.5430/ijba.v2n4p33

Babajide, A.A., Adegboye, F.B. \& Omankhanlen, A.E., 2015, 'Financial inclusion and economic growth in Nigeria', International Journal of Economics and Financial Issues 5(3), 5-12.

Baltagi, B.H., 1999, 'Applied econometrics rankings: 1989-1995', Journal of Applied Econometrics 14(4), 423-441.

Baltagi, B.H., 2008, 'Forecasting with panel data', Journal of forecasting 27(2), 153-173.

Banya, R.M. \& Biekpe, N., 2017, 'Bank competition and economic growth: Empirical evidence from selected frontier African countries', Journal of Economic Studies 44(2), 245-265. https://doi.org/10.1108/JES-09-2015-0169

Barajas, M.A., Chami, M.R. \& Yousefi, M.R., 2013, The finance and growth nexus re-examined: Do all countries benefit equally? No. 13-130, International Monetary Fund, Washington, DC.

Bayar, Y. \& Gavriletea, M.D., 2018, 'Peace, terrorism and economic growth in Middle East and North African countries', Quality \& Quantity 52(5), 2373-2392.

Berger, A.N., Klapper, L.F. \& Turk-Ariss, R., 2009, 'Bank competition and financial stability', Journal of Financial Services 35, 99-118. https://doi.org/10.1007/ s10693-008-0050-7

Bigirimana, M. \& Hongyi, X., 2018, 'Research on relationship between financial inclusion and economic growth of Rwanda: Evidence from commercial banks with ARDL approach', International Journal of Innovation and Economic Development 4(1), 7-18. https://doi.org/10.18775/ijied.1849-7551-7020.2015.41.2001

Bildirici, M.E. \& Kayıkçı, F., 2013, 'Effects of oil production on economic growth in Eurasian countries: Panel ARDL approach', Energy 49(1), 156-161. https://doi. org/10.1016/j.energy.2012.10.047

Boot, A.W. \& Thakor, A.V., 2000, 'Can relationship banking survive competition?', The Journal of Finance 55(2), 679-713. https://doi.org/10.1111/0022-1082.00223

Camara, N.P.X. \& Tuesta, D., 2014, Factors that matter for financial inclusion: Evidence from Peru, BBVA Working Paper, Madrid.

Carbo-Valverde, S., Rodriguez-Fernandez, F. \& Udell, G.F., 2009, 'Bank market power and SME financing constraints', Review of Finance 13(2), 309-340. https://doi. org/10.1093/rof/rfp003

Choi, I., 2001, 'Unit root tests for panel data', Journal of International Money and Finance 20(2), 249-272. https://doi.org/10.1016/S0261-5606(00)00048-6

Chortareas, G.E., Girardone, C. \& Ventouri, A., 2011, 'Financial frictions, bank efficiency and risk: Evidence from the Eurozone', Journal of Business Finance \& Accounting 38(1-2), 259-287. https://doi.org/10.1111/j.1468-5957.2010.02226.x

Claessens, S. \& Laeven, L., 2005, 'Financial dependence, banking sector competition, and economic growth', Journal of the European Economic Association 3(1), 179-207. https://doi.org/10.1162/1542476053295322

Claessens, S., 2009, 'Competition in the financial sector: Overview of competition policies', The World Bank Research Observer 24(1), 83-118.

Dahiya, S. \& Kumar, M., 2020, 'Linkage between financial inclusion and economic growth: An empirical study of emerging Indian economy', Vision 24(2), 184-193. https://doi.org/10.1177/0972262920923891

Demirgüç-Kunt, A., Klapper, L. \& Singer, D., 2017, Financial inclusion and inclusive growth: A review of recent empirical evidence, The World Bank, Washington, DC.

Demirgüç-Kunt, A., Klapper, L., Singer, D., Ansar, S. \& Hess, J., 2018, The Globa Findex Database 2017: Measuring financial inclusion and the fintech revolution, The World Bank, Washington, DC.

Engle, R.F. \& Granger, C.W., 1987, 'Co-integration and error correction representation, estimation, and testing', Econometrica: Journal of the Econometric Society, 251-276.

Evans, O., 2015, 'The effects of economic and financial development on financial inclusion in Africa', Review of Economic and Development Studies 1, 17-25. https://doi.org/10.26710/reads.v1i1.113

Evans, O. \& Alenoghena, O.R., 2017, 'Financial inclusion and GDP per capita in Africa: A Bayesian VAR model', Journal of Economics \& Sustainable Development 8(18), 44-57.

Evans, O. \& Lawanson, O., 2017, 'A multi-sectoral study of financial inclusion and economic output in Nigeria', Ovidius University Annals, Economic Sciences Series 17(1), 195-204.

Gretta, S.A.A.B., 2017, 'Financial inclusion and growth', The Business \& Management Review 8(4), 434.

Gour'ene, G.A.Z. \& Mendy, P., 2017, Financial inclusion and economic growth in WAEMU: A multiscale heterogeneity panel causality approach, Munich Personal RePEc Archive, Germany. 
GPFI, 2010, G20 principles for innovative financial inclusion - Executive brief, viewed 10 October 2020, from http://www.gpfi.org/publications/g20-principlesinnovative-financial-inclusion-executive-brief.

Guzman, M., 2000, 'Bank structure, capital accumulation and growth: A simple macroeconomic model', Economic Theory 16, 421-455. https://doi.org/10.1007/ PL00004091

Hausman, J.A., 1978, 'Specification tests in econometrics', Econometrica: Journal of the Econometric Society, 1251-1271.

Hauswald, R. \& Marquez, R., 2006, 'Competition and strategic information acquisition in credit markets', The Review of Financial Studies 19(3), 967-1000. https://doi. org/10.1093/rfs/hhj021

Hoffman, D.L. \& Rasche, R.H., 1996, 'Assessing forecast performance in a cointegrated system', Journal of Applied Econometrics 11(5), 495-517.

Hsiao, C., 2014, Analysis of panel data (No. 54), Cambridge University Press, Cambridge.

Idun, A.A.A. \& Aboagye, A.Q., 2014, 'Bank competition, financial innovations and economic growth in Ghana', African Journal of Economic and Management Studies 31(2), 40-45. https://doi.org/10.2139/ssrn.2199130

Ijaz, S., Hassan, A., Tarazi, A. \& Fraz, A., 2020, 'Linking bank competition, financia stability, and economic growth', Journal of Business Economics and Managemen 21(1), 200-221.

Iqbal, B.A. \& Sami, S., 2017, 'Role of banks in financial inclusion in India', Contaduría y administración 62(2), 644-656.

Johansen, S. \& Juselius, K., 1990, 'Maximum likelihood estimation and inference on cointegration - With applications to the demand for money', Oxford Bulletin of cointegration - With applications to the demand for money', Oxford Bulletin of
Economics and Statistics 52(2), 169-210. https://doi.org/10.1111/j.1468Economics and Statistics

Kim, D.W., Yu, J.S. \& Hassan, M.K., 2018, 'Financial inclusion and economic growth in OIC countries', Research in International Business and Finance 43, 1-14. https:// doi.org/10.1016/j.ribaf.2017.07.178

Kumar, S., 2013, 'Impact of bank mergers on the efficiency of banks: a study of merger of Bharat Overseas Bank with Indian Overseas Bank', International Journal of Academic Research in Business and Social Sciences 3(12), 221.

Khalaf, A.H. \& Ali, A.H., 2015, 'Financial inclusion and economic development in Iraq', International Journal of Science and Research 78(96), 1758-1767.

Lenka, S.K. \& Sharma, R., 2017, 'Does financial inclusion spur economic growth in India?', The Journal of Developing Areas 51(3), 215-228. https://doi.org/10.1353/ jda.2017.0069

Levine, R., 2005, 'Finance and growth: Theory and evidence', Handbook of Economic Growth 1, 865-934. https://doi.org/10.1016/S1574-0684(05)01012-9

Loayza, N. \& Rancière, R., 2006, 'Financial development, financial fragility, and growth', Journal of Money, Credit and Banking 38(4), 1051-1076. https://doi. org/10.1353/mcb.2006.0060

Love, I. \& Martínez Pería, M.S., 2014, 'How bank competition affects firms' access to finance', The World Bank Economic Review 29(3), 413-448. https://doi. org/10.1093/wber/lhu003

Love, I. \& Martínez Pería, M.S., 2015, 'How bank competition affects firms' access to finance', The World Bank Economic Review 29(3), 413-448.

Marín, A.G. \& Schwabe, R., 2019, 'Bank competition and financial inclusion: Evidence from Mexico', Review of Industrial Organization 55(2), 257-285.

Marquez, R., 2002, 'Competition, adverse selection, and information dispersion in the banking industry', The Review of Financial Studies 15(3), 901-926. https://doi. org/10.1093/rfs/15.3.901

MacKinnon, J.G., Haug, A.A. \& Michelis, L., 1999, 'Numerical distribution functions of likelihood ratio tests for cointegration', Journal of applied Econometrics 14(5), 563-577.

Mehrotra, A. \& Yetman, J., 2015, 'Financial Inclusion - Issues for Central Banks. BIS Quarterly Review', Bank for International Settlements, Basel 24(3), 115-118.
Mengistu, A. \& Saiz, H.P., 2018, Financial inclusion and bank competition in subSaharan Africa, International Monetary Fund, Washington, DC.

Mishkin, F.S. \& Serletis, A., 2011, The economics of money, banking and financial markets, 4th Canadian edn., Pearson, Toronto.

Muhoza, B.K., 2019, 'Financial intermediation and economic growth in the East African Community: A financial index approach', African Journal of Economic Review 7(2), 165-182.

Mwaitete, C.P. \& George, L.A., 2018, 'Financial inclusion and economic growth a regression analysis', Imperial Journal of Interdisciplinary Research 4(1), 265-288.

Okoye, L.U., Erin, O. \& Modebe, N.J., 2017, 'Financial inclusion as a strategy for enhanced economic growth and development', The Journal of Internet Banking and Commerce 35(8), 1-14.

Onaolapo, A.R., 2015, 'Effects of financial inclusion on the economic growth of Nigeria (1982-2012)', International Journal of Business and Management Review 3(8), $11-28$.

Oruo, J., 2013, 'The relationship between financial inclusion and GDP growth in Kenya', Doctoral dissertation, University of Nairobi, Nairobi.

Otiwu, K.C., Okere, P.A., Uzowuru, L.N. \& Ozuzu, P.N., 2018, 'Financial inclusion and economic growth of Nigeria (the microfinance option)', International Journal for Innovation Education and Research 6(2), 61-74. https://doi.org/10.31686/ijier.vol6.iss2.949

Owen, A.L. \& Pereira, J.M., 2018, 'Bank concentration, competition, and financial inclusion', Review of Development Finance 8(1), 1-17. https://doi.org/10.1016/j. rdf.2018.05.001

Pesaran, M.H., Shin, Y. \& Smith, R.P., 1999, 'Pooled mean group estimation of dynamic heterogeneous panels', Journal of the American Statistical Association 94(446), 621-634. https://doi.org/10.1080/01621459.1999.10474156

Rakshit, B. \& Bardhan, S., 2019, 'Does bank competition promote economic growth? Empirical evidence from selected South Asian countries', South Asian Journal of Business Studies 5(2), 115-142

Rasheed, B., Law, S.H., Chin, L. \& Habibullah, M.S., 2016, 'The role of financial inclusion in financial development: International evidence', Abasyn University Journal of Social Sciences 9(2), 330-348.

Sarma, M., 2008, Index of financial inclusion, No. 215, IMF Working Paper, Washington D.C.

Sarma, M., 2012, 'Index of Financial Inclusion - A measure of financial sector inclusiveness', Centre for International Trade and Development, School of International Studies Working Paper Jawaharlal Nehru University, Delhi, India.

Sahay R., Cihak, M., N’Diaye, P.M., Barajas, A., Mitra, S., Kyobe, A. et al., 2015 Financial inclusion: Can it meet multiple macroeconomic goals?, IMF Staf Discussion Notes 15/17, International Monetary Fund, viewed n.d., https://www. imf.org/external/pubs/ft/sdn/20.

Sharma, D., 2016, 'Nexus between financial inclusion and economic growth: Evidence from the emerging Indian economy', Journal of Financial Economic Policy 8(1) 13-36. https://doi.org/10.1108/JFEP-01-2015-0004

Sethi, D. \& Acharya, D., 2018, 'Financial inclusion and economic growth linkage: Some cross country evidence', Journal of Financial Economic Policy 10(3), 369-385. https://doi.org/10.1108/JFEP-11-2016-0073

Van, L.T.H., Vo, A.T., Nguyen, N.T. \& Vo, D.H., 2019, 'Financial inclusion and economic growth: An international evidence', Emerging Markets Finance and Trade 57(1) 239-263. https://doi.org/10.1080/1540496X.2019.1697672

World Bank Group, 2012, 2014, World development indicators 2012 and 2014, World Bank Publications, Washington, DC.

World Bank Group, 2017, World development indicators 2016, World Bank Publications, Washington, DC

Zhang, R. \& Naceur, S.B., 2019, 'Financial development, inequality, and poverty: Some international evidence', International Review of Economics \& Finance 61, 1-16. 


\section{Appendix 1: Supplementary Results}

TABLE 1-A1: Lag length selection.

\begin{tabular}{|c|c|c|c|c|c|c|}
\hline Lag & LogL & LRT & FPE & AIC & SIC & HQC \\
\hline 0 & -4486.877 & N/A & 739.7706 & 20.79573 & 20.84281 & 20.81432 \\
\hline 1 & -2371.346 & 4172.297 & 0.046327 & 11.11734 & $11.39987 \dagger$ & 11.22888 \\
\hline 2 & -2362.107 & 18.00670 & 0.049836 & 11.19031 & 11.70828 & 11.39480 \\
\hline 3 & -2349.272 & $24.71854 \dagger$ & $0.052729 \dagger$ & $11.24663 \dagger$ & 12.00004 & $11.54408 \dagger$ \\
\hline 4 & -2329.901 & 36.85987 & 0.054133 & 11.27269 & 12.26154 & 11.66308 \\
\hline 5 & -2100.885 & 430.4652 & 0.021058 & 10.32817 & 11.55247 & 10.81152 \\
\hline
\end{tabular}

LRT, Likelihood Ratio test; FPE, Final Prediction Error; AIC, Akaike information criterion; SIC, Schwarz information criteria; HQC, Hannan and Quinn criteria.

$\dagger$, Indicates lag order designated by the criterion.

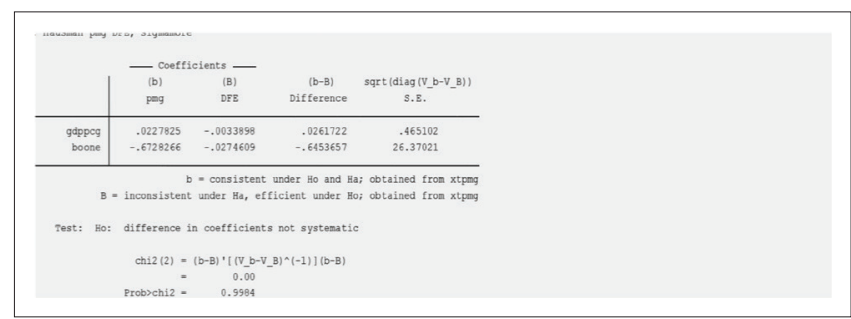

FIGURE 1-A1: Hausman test results.

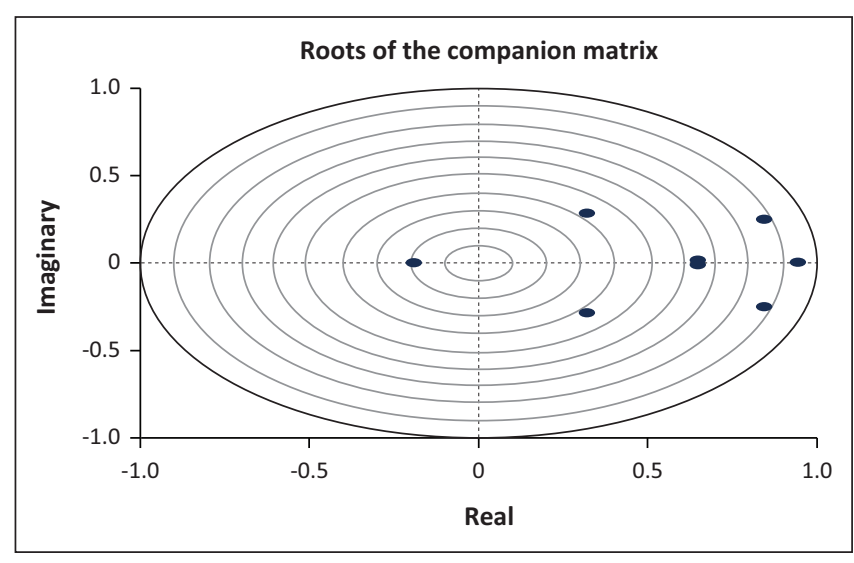

FIGURE 2-A1: Stability test. 